\title{
RECAPTURE RATE, GROWTH AND SEX OF STOCKED CULTURED EELS ANGUILLA ANGUILLA (L.).
}

\author{
M.I. PEDERSEN \\ Danish Institute for Fisheries Research, Department of Inland Fisheries, Vejlsøvej 39, \\ 8600 Silkeborg, Denmark.
}

\begin{abstract}
A total of 84,791 Alcian blue marked eels, size range $15-33 \mathrm{~cm}$, were released in a lake, a fjord and an open coastal area. Recaptures were made by fishermen up to 4 years following release. Recaptures were most successful at the freshwater lake where $12.6 \%$ were recaptured, $2.7 \%$ in the fjord and $0.2 \%$ at the open coast. Length increment was estimated to be between 2.5 and $6.5 \mathrm{~cm}$ annually. The sex ratio (female/male) of yellow eels increased in subsequent years of recaptures, possibly as a result of environmental sex determination following release. The use of Alcian blue for a long-term marking experiment, based on samplings by fishermen, are concluded to be questionable.
\end{abstract}

Key-words : Anguilla, stocking, recapture rate, growth, sex.

\begin{abstract}
TAUX DE RECAPTURE, CROISSANCE ET SEXE D'ANGUILLES (ANGUILLA ANGUILLA L.) ALEVINÉES À PARTIR D'ÉLEVAGE.
\end{abstract}

\section{RÉSUMÉ}

Un total de 84791 anguilles marquées au bleu alcian, de taille comprise entre 15 et $33 \mathrm{~cm}$, ont été relâchées dans un lac, un fjord et une aire côtière ouverte. Des recaptures ont été faites par des pêcheurs jusqu'à 4 ans après le relâchage. Les recaptures ont été les plus réussies dans le lac d'eau douce où $12,6 \%$ ont été recapturées, $2,7 \%$ dans le fjord et $0,2 \%$ dans la côte ouverte. L'accroissement de la taille a été évalué entre 2,5 et $6,5 \mathrm{~cm}$ par année. Le sex-ratio (femelle/mâle) des anguilles jaunes a augmenté avec les années successives de recapture, peut-être à la suite d'une détermination environnementale du sexe après le relâchage. II est conclu que l'utilisation du bleu alcian pour une expérience de marquage à long terme, basée sur des échantillonnages effectués par des pêcheurs, reste discutable.

Mots-clés : Anguilla, alevinage, taux de recapture, croissance, sexe. 


\section{INTRODUCTION}

A drastic decline in the Danish eel stocks during the past 30 years is evident from the official catches. In the 1960s the yearly catch fluctuated between 3,197 and 4,723 tonnes and in the 1990s it has dropped to 1,023 - 1,568 tonnes. The decline in eel stocks coincides with a notable decrease in recruitment to the Baltic beginning in the $1940 \mathrm{~s}$ (HAGSTRÖM and WICKSTRÖM, 1990). Throughout Europe a general decline in recruitment has been recorded since the beginning of the 1980s (MORIARTY, 1990).

To enhance eel populations, and utilize the production capacity of inland waters deficient of eel, a national stocking programme was initiated in 1987 (RASMUSSEN and GEERTZ-HANSEN, 1998). The government and fish licence funded the programme and particular streams and rivers, with public access to the fishery, were stocked. In 1990 the stocking programme was expanded to coastal areas and during the 1990 s between 2.5 and 8.5 million elvers have been released annually.

Results from stocking have been achieved in streams, with regard to the method of stocking (spot versus scatter), growth and mortality rates of stocked fry (BISGAARD and PEDERSEN, 1991 ; BERG and JØRGENSEN, 1994). The time schedule for the experiments has been short, 3 - 12 months, and no result of yield is available for streams. Long-term stocking in closed freshwater systems has been described with positive results of yield by TULONEN and PURSIAINEN (1992) and WICKSTRÖM et al. (1996). Results from stocking eels in open marine water systems are difficult to achieve, especially due to the lack of appropriate methods of marking or tagging eels. Apart from this study, the only other known study in open marine water systems has been undertaken by ANDERSSON et al. (1991), who marked elvers with radioactive europium at the coast of the Baltic proper.

In order to achieve some experience from stockings : a lake, a fjord and an open coast were stocked with Alcian blue marked eels in 1988. The aim was to obtain information on the value of cultured eels as stocking material (NIELSEN, 1989). Cultured eels are grown under high densities and the feed is artificial. In aquaculture a dominance of males is observed and growth of males stops at a length of about $40 \mathrm{~cm}$ (EGUSA, 1979). Status reports from returned eels in 1988 and 1989 have been reported by NIELSEN (1989) and NIELSEN (1990).

\section{Study sites}

Hjarbæk Fjord (Figure 1) is a shallow inlet of the Limfjord with a water surface of $25 \mathrm{~km}^{2}$. The mean and maximum depth is 2 and $6.5 \mathrm{~m}$. During $1966-1991$ a sluice was operating, preventing saltwater to penetrate and turned Hjarbæk Fjord into a freshwater lake with affluent from 4 streams.

The Isefjord covers a water surface of $305 \mathrm{~km}^{2}$. Freshwater affluent is primarily surface run off. The salinity is $18 \mathrm{ppt}$, mean and maximum depth is 5 and $17 \mathrm{~m}$.

South Funen : this area is an open coast between the isles Tasinge and Langeland and with a salinity of about $12-14$ ppt. The area is flat with a gravel bottom patchy vegetation and depth is less than $4 \mathrm{~m}$. 


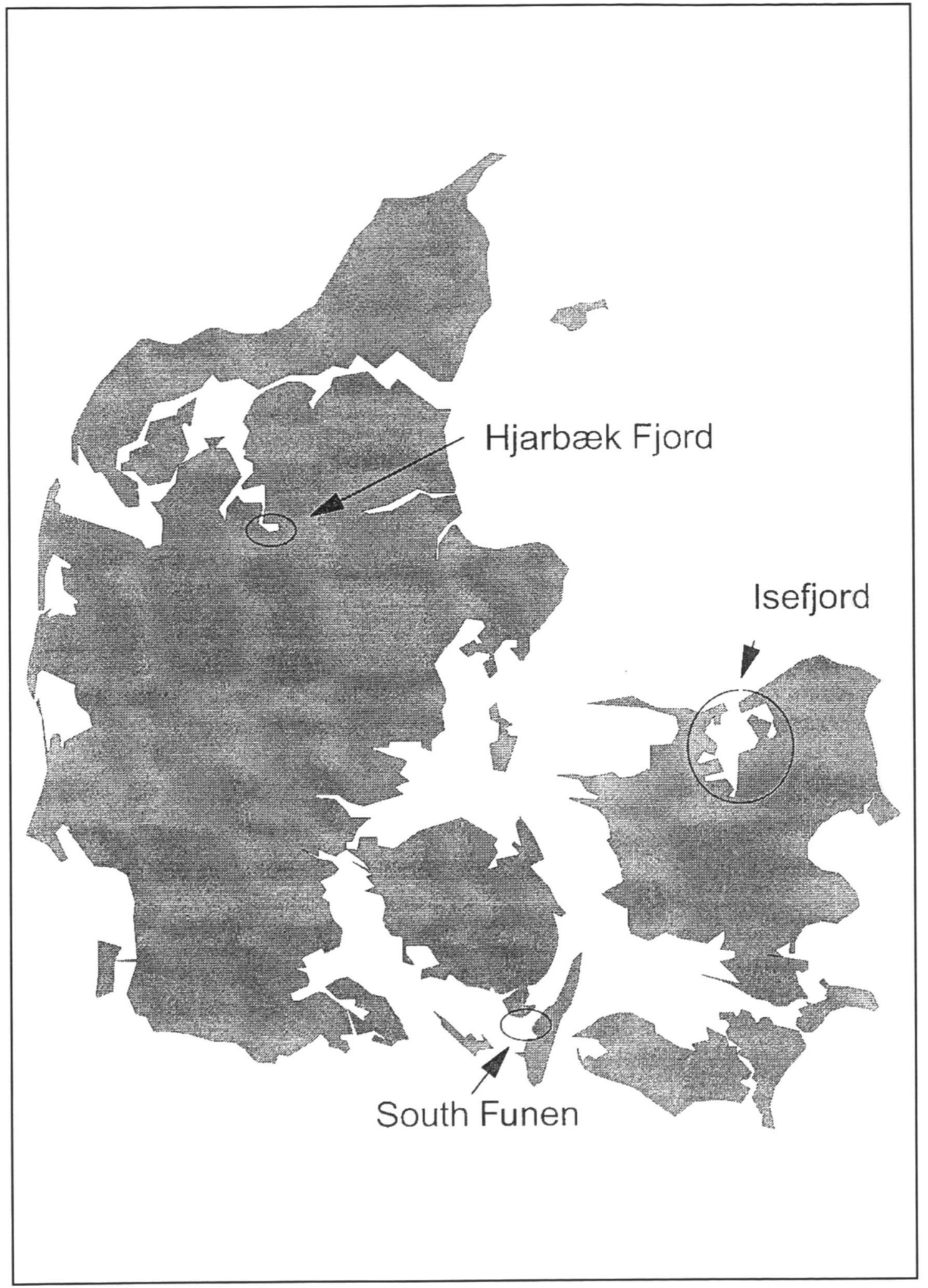

Figure 1

Map of Denmark with study sites.

Figure 1

Carte du Danemark avec les sites de l'étude. 


\section{MATERIAL AND METHODS}

The eels used in the experiment were imported from France and England as glass eels and cultured until release. After about $6-12$ months of feeding the eels were sorted according to length in 3 batches : $15-22,23-26$ and $27-33 \mathrm{~cm}$. Each batch was given a different mark code by 1 - 3 Alcian blue spots, ventrally, by use of a jet inoculator (HART and PITCHER, 1969). A total of 84,791 eels were marked and released during June, August and October with an approximate density of 40 eels/ha at the study sites. Length, weight and sex were measured from subsamples. NIELSEN (1989) mentions that some minor growth might have occurred between marking and release because of time lag between marking and release. The sex was determined macroscopically (SINHA and JONES, 1966). All the examined eels were either male or undifferentiated (Table I).

The fishermen were requested to return marked eels no matter legal size, which is $38.0 \mathrm{~cm}$ at Hjarbæk Fjord and $35.5 \mathrm{~cm}$ at the other study sites. The standard mesh size in the cod end of fykes and pound nets is $11 \mathrm{~mm}$ (knot to knot) and eels of length less than approximately $35 \mathrm{~cm}$ are not fully retained in the fishing gear. Returned eels were examined with regard to batch, yellow/silver stage, sex, length $(0.5 \mathrm{~cm})$, and weight $(1 \mathrm{~g})$. The mean annual growth increment in Table I was calculated for each batch by using pooled length data. This was done by subtracting mean length at recapture $(L r)$ from mean length at time of release (Lo) according to $\mathrm{Gr}=(\mathrm{Lc}-\mathrm{Lo}) /(\mathrm{Lt}-\mathrm{Lo})$, where ( $\mathrm{Lt}-\mathrm{Lo})$ represents the time between release and recapture. When length data from 1989 were used, $(L t-L o)=2$, assuming 2 growth seasons.

\section{Table I}

Total number of marked eels released in 1988. Length, weight and sex measured from subsamples $(N=100)$.

\section{Tableau I}

Nombre total des anguilles marquées relâchées en 1988. La longueur, le poids et le sexe sont mesurés à partir de sous-échantillons $(\mathrm{N}=100)$.

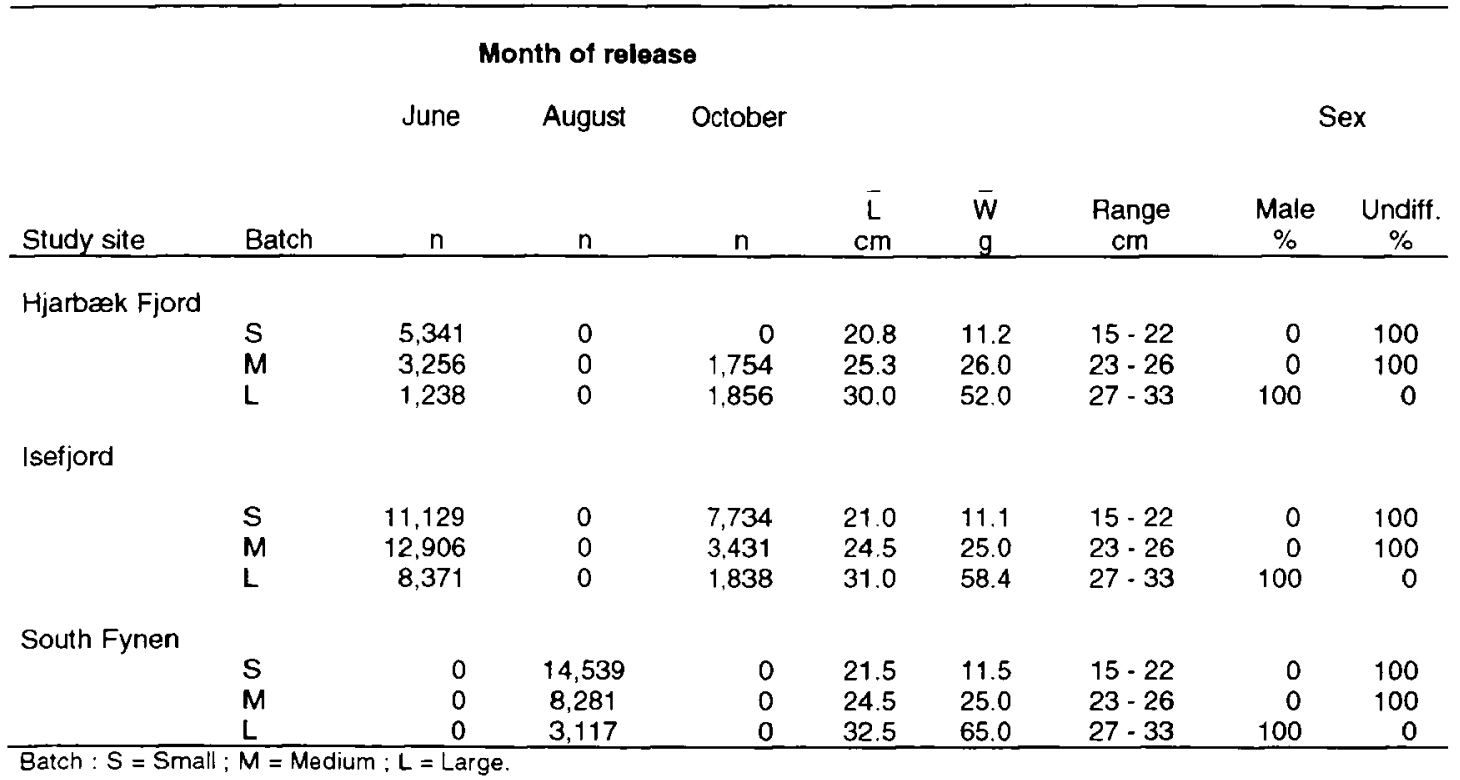




\section{RESULTS}

\section{Recapture rate}

During 1988 - 1992 recaptures totalled 2,985 marked eels. The return of marked eels was most successful at Hjarbæk Fjord; at this site $12.6 \%$ of the released eels were recaptured. At the Isefjord only $2.7 \%$ were recaptured and of these $90 \%$ were caught in the year of release. At the open coast at South Funen very few eels were recaptured, $0.2 \%$. At all study sites large eels were represented with the highest recapture rate (Table II).

\section{Table II}

Recaptures of batch marked eels released in 1988. Gr = estimated annual growth rate.

\section{Tableau II}

Recaptures des lots d'anguilles marquées relâchées en 1988. Gr $=$ taux de croissance annuel estimé.

\begin{tabular}{|c|c|c|c|c|c|c|c|c|c|c|}
\hline & \multicolumn{10}{|c|}{ Recaptures } \\
\hline & Batch & $\begin{array}{c}\text { Released } \\
n\end{array}$ & $\begin{array}{c}1988 \\
n\end{array}$ & $\begin{array}{c}1989 \\
\mathrm{n}\end{array}$ & $\begin{array}{c}1990 \\
n\end{array}$ & $\begin{array}{c}1991 \\
n\end{array}$ & $\begin{array}{c}1992 \\
n\end{array}$ & $\begin{array}{c}\text { Total } \\
\mathbf{n}\end{array}$ & $\begin{array}{c}\text { Total } \\
\% \\
\end{array}$ & $\begin{array}{c}\mathrm{Gr} \\
\mathrm{cm}\end{array}$ \\
\hline \multicolumn{11}{|l|}{ Hjarbæk } \\
\hline & S & 5,341 & 10 & 101 & 62 & 0 & 1 & 174 & 3,3 & 5.3 \\
\hline & $M$ & 5,010 & 243 & 508 & 82 & 0 & 13 & 846 & 16.9 & 3.4 \\
\hline & $L$ & 3,094 & 476 & 188 & 8 & 0 & 0 & 672 & 21.7 & 2.5 \\
\hline & Total & 13,445 & & & & & & 1,692 & 12.6 & \\
\hline DSElord & $\mathrm{S}$ & 18,863 & 27 & 0 & 0 & 0 & 0 & 27 & 0.2 & 2.4 \\
\hline & $M$ & 16,337 & 146 & 1 & 5 & 1 & 0 & 153 & 0.9 & 5.2 \\
\hline & L & 10,209 & 963 & 86 & 3 & 2 & 0 & 1,054 & 10.3 & 4.5 \\
\hline & Total & 45,409 & & & & & & 1,234 & 2.7 & \\
\hline \multicolumn{11}{|l|}{ South Fynen } \\
\hline & S & 14,539 & 0 & 2 & 2 & 0 & 0 & 4 & $<0.1$ & $\cdot$ \\
\hline & $M$ & 8,281 & 0 & 4 & 16 & 0 & 0 & 20 & 0.2 & 6.5 \\
\hline & $\mathrm{L}$ & 3,117 & 3 & 18 & 11 & 0 & 0 & 32 & 1.0 & 4.3 \\
\hline & Total & 25,937 & & & & & & 56 & 0.2 & \\
\hline
\end{tabular}

\section{Growth}

A plot of length increment of recaptures against time, for the 3 different cohorts at Hjarbæk Fjord is presented in Figure $2 a-b-c$. The figures show that mean length at recapture varied little during the fishing season, May to October. From pooled length at catch data the mean growth increment was estimated to be between 2.5 and $6.5 \mathrm{~cm}$ annually (Table I). Differences in length between males and females were small but females were in some cases significantly larger (Table III). 


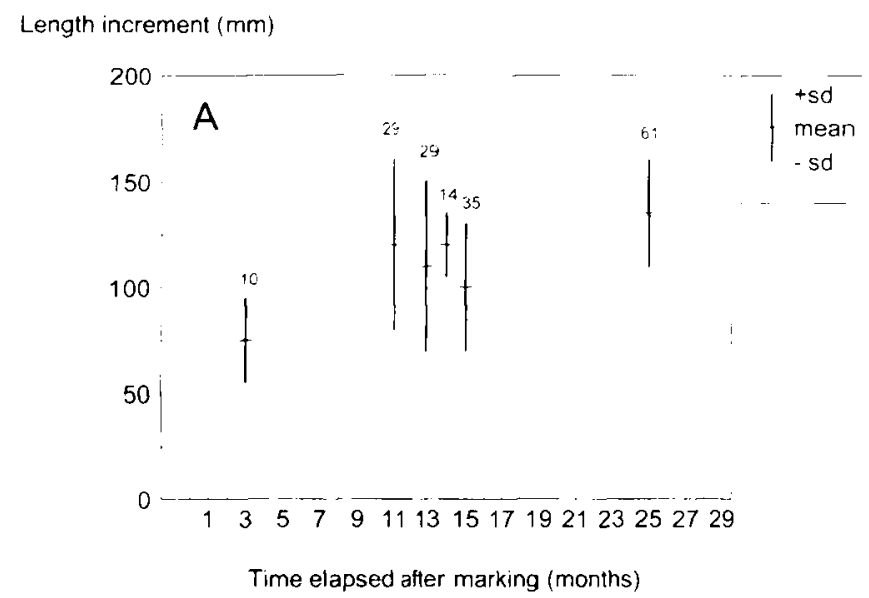

Length increment $(\mathrm{mm})$
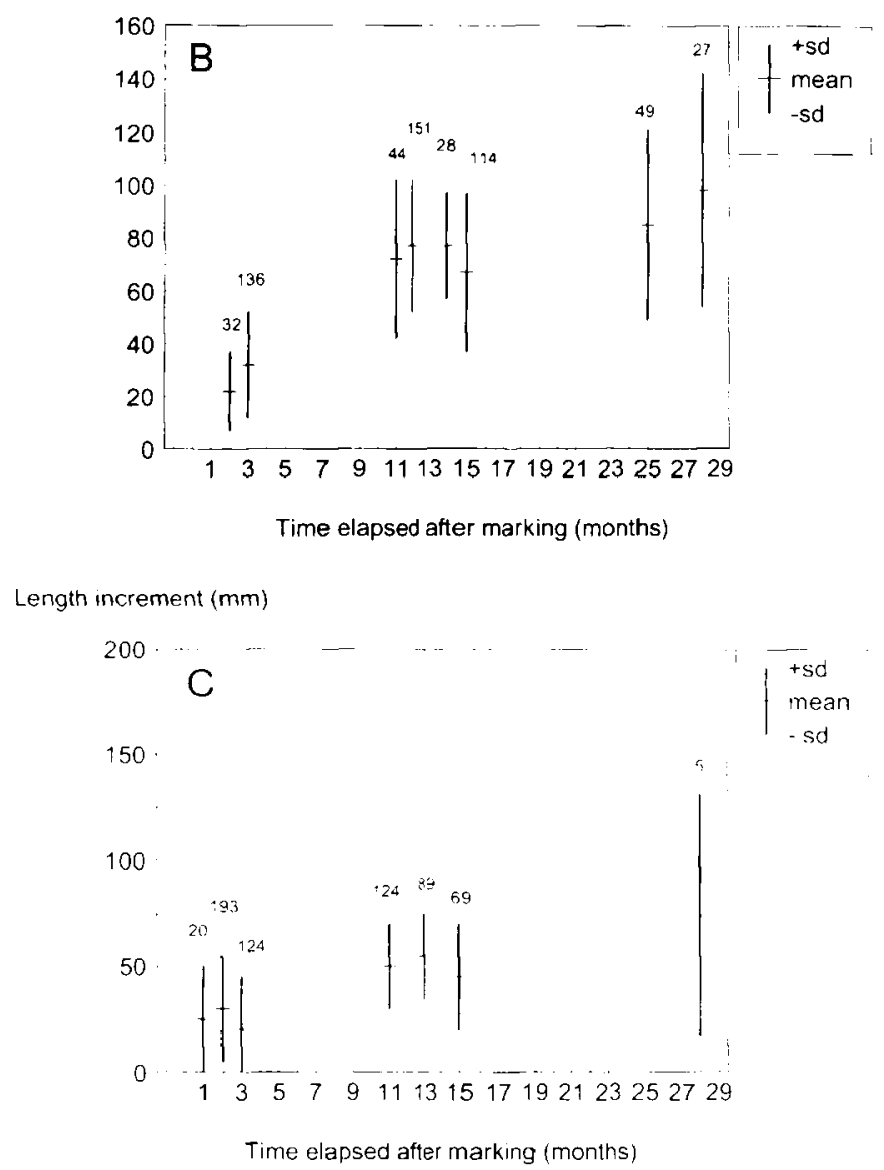

Figure 2

Length increment $(\mathrm{mm})$ between size at recapture and release at Hjarbæk Fjord. Month number 1 refers to July 1988. A) Small eels ; B) Medium eels ; C) Large eels. The number in each month is given on top.

\section{Figure 2}

Accroissement de la longueur $(\mathrm{mm})$ entre la taille à la recapture et au relâchage dans le fjord Hjarbæk. Le mois numéro 1 se rapporte à juillet 1988. A) Petites anguilles ; B) Anguilles moyennes ; C) Grandes anguilles. Le nombre pour chaque mois est indiqué en haut. 
Table III

Length and weight of yellow eels from Hjarbæk Fjord.

\section{Tableau III}

Longueur et poids des anguilles jaunes du fjord Hjarbæk.

\begin{tabular}{|c|c|c|c|c|c|c|c|c|c|c|c|}
\hline & & & & Femal & & & & & $\mathrm{Ma}$ & & \\
\hline Year & Batch & $n$ & $\begin{array}{c}\bar{L} \\
\mathrm{~cm}\end{array}$ & SD & $\begin{array}{c}\bar{W} \\
\mathrm{~g}\end{array}$ & $\mathrm{SD}$ & $n$ & $\begin{array}{c}\bar{L} \\
\mathrm{~cm}\end{array}$ & $\mathrm{SD}$ & $\begin{array}{c}\bar{w} \\
g\end{array}$ & SD \\
\hline $\begin{array}{l}1988 \\
1989 \\
1990\end{array}$ & $\begin{array}{l}S \\
S \\
S\end{array}$ & $\begin{array}{r}0 \\
53 \\
53\end{array}$ & $\begin{array}{c}- \\
31.4 \\
34.6\end{array}$ & $\begin{array}{l}(3.3) \\
(3.6)\end{array}$ & $\begin{array}{c}- \\
53 \\
71\end{array}$ & $\begin{array}{c}- \\
(20) \\
(21)\end{array}$ & $\begin{array}{r}7 \\
43 \\
6\end{array}$ & $\begin{array}{l}27.9 \\
31.4 \\
32.7\end{array}$ & $\begin{array}{l}(1.5) \\
(3.7) \\
(1.9)\end{array}$ & $\begin{array}{l}34 \\
56 \\
60\end{array}$ & $\begin{array}{r}(8) \\
(18) \\
(10)\end{array}$ \\
\hline $\begin{array}{l}1988 \\
1989 \\
1990 \\
1992\end{array}$ & $\begin{array}{l}M \\
M \\
M \\
M\end{array}$ & $\begin{array}{r}14 \\
197 \\
55 \\
3\end{array}$ & $\begin{array}{l}30.0 \\
32.5 \\
33.3 \\
33.6\end{array}$ & $\begin{array}{l}(2.4) \\
(2.3) \\
(3.2) \\
(2.3)\end{array}$ & $\begin{array}{l}45 \\
59 \\
62 \\
58\end{array}$ & $\begin{array}{l}(14) \\
(17) \\
(19) \\
(21)\end{array}$ & $\begin{array}{r}193 \\
247 \\
8 \\
1\end{array}$ & $\begin{array}{l}28.4 \\
32.8 \\
32.3 \\
32.5\end{array}$ & $\begin{array}{c}(2.1) \\
(2.5) \\
(3.0) \\
\end{array}$ & $\begin{array}{l}39 \\
62 \\
64 \\
57\end{array}$ & $\begin{array}{c}(11) \\
(16) \\
(20) \\
-\end{array}$ \\
\hline $\begin{array}{l}1988 \\
1989 \\
1990\end{array}$ & $\begin{array}{l}{ }^{*} \mathrm{~L} \\
{ }^{*} \mathrm{~L} \\
\mathrm{~L}\end{array}$ & $\begin{array}{r}26 \\
27 \\
5\end{array}$ & $\begin{array}{l}34.6 \\
36.2 \\
39.7\end{array}$ & $\begin{array}{l}(2.7) \\
(2.0) \\
(6.9)\end{array}$ & $\begin{array}{r}63 \\
78 \\
121\end{array}$ & $\begin{array}{l}(15) \\
(15) \\
(78)\end{array}$ & $\begin{array}{r}432 \\
131 \\
3\end{array}$ & $\begin{array}{l}32.7 \\
34.8 \\
35.5\end{array}$ & $\begin{array}{l}(2.4) \\
(1.9) \\
(0.7)\end{array}$ & $\begin{array}{l}63 \\
74 \\
72\end{array}$ & $\begin{array}{l}(15) \\
(14) \\
(17)\end{array}$ \\
\hline
\end{tabular}

"Denotes significant difference in length of male $v s$ female (t-test ; $p<0,05$ ).

\section{Sex and silvering}

At time of release, sex was unknown due to undifferentiated gonads in the smallest size groups $(S+M)$. In the large size group $(L)$ the percentage of males was recorded to be $100 \%$ (Table I). The sex ratio of recaptured eels at Hjarbæk Fjord shows that the percentage of females increases in subsequent years of recapture (Figure 3). At the open coast at South Funen recaptures in 1990 were also in favour of females with 88 and $91 \%$ of females in medium and large eels, respectively. At the Isefjord only $5 \%$ of the 1989 recaptures were females.

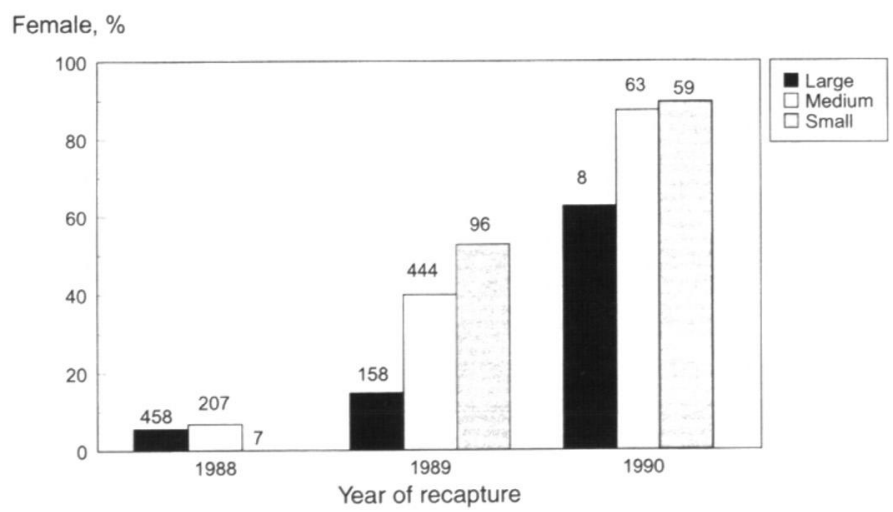

Figure 3

Sex ratio of yellow eels recaptured at Hjarbæk Fjord. The number of examined eels is given on top of bars.

Figure 3

Sex-ratio des anguilles jaunes recapturées dans le fjord Hjarbæk. Le nombre des anguilles examinées est indiqué en haut des barres. 
Male silver eels were present in recaptures in 1988 and 1989. A total of 125 male silver eels were recorded with a mean length of $35.2 \mathrm{~cm}$ (SD 1.9) in the size range 30.5 to $40.5 \mathrm{~cm}$. In 1989 silver eels make up $30 \%$ of the recaptures of large and $10 \%$ of medium eels (Table IV).

\section{Table IV}

Silver eels in \% of total recaptures from Hjarbæk Fjord.

\section{Tableau IV}

Anguilles argentées en \% des recaptures totales dans le fjord Hjarbæk.

\begin{tabular}{llrrrccc}
\hline Year & Batch & $\mathrm{n}$ & $\%$ & $\begin{array}{c}\overline{\mathrm{L}} \\
\mathrm{cm}\end{array}$ & $\begin{array}{c}\min -\max \\
\mathrm{cm}\end{array}$ & $\begin{array}{c}\bar{W} \\
\mathrm{~g}\end{array}$ & $\begin{array}{c}\min -\max \\
\mathrm{g}\end{array}$ \\
\hline \multirow{2}{*}{1988} & $\mathrm{~L}$ & 12 & 2.5 & 34.1 & $30.5-40.5$ & 70 & $53-96$ \\
& $\mathrm{M}$ & 0 & - & - & - & - & - \\
& $\mathrm{S}$ & 0 & - & - & - & - & - \\
1989 & $\mathrm{~L}$ & 57 & 30.3 & 36.0 & $31.0-38.0$ & 82 & $50-115$ \\
& $\mathrm{M}$ & 51 & 10.1 & 34.6 & $30.5-37.5$ & 77 & $48-104$ \\
& $\mathrm{~S}$ & 5 & 5.0 & 34.0 & $34.0-40.0$ & 80 & $64-107$ \\
\hline
\end{tabular}

\section{DISCUSSION - CONCLUSION}

Recapture rates are influenced by several factors : visibility of the mark, gear selectivity for size, fishermen's intention to examine their catches for eels with marks, migration out of study site, fishing effort and mortality factors. A very important factor is visibility of the mark. In NIELSEN's (1988) review on marking and tagging methods applied to the eel, Alcian blue is recommended as a promising and relevant marking method. DEKKER (1989) found that the visibility of the Alcian blue mark was too weak to rely on recaptures from commercial fishermen or anglers. This accords with observations from a small Danish lake stocked with Alcian blue marked eels. Results from this lake show that the mark is still clear, but not on the outside of the fish 7 years after release (unpublished data). To identify the Alcian blue mark the skin needs to be removed and often a cut deep in the flesh needs to be done. The impression is that visibility of the mark on the outside of the fish is inversely related to growth rate.

The reason for the high recapture rate at Hjarbæk Fjord compared to Isefjord and South Funen is unknown. In general marked eels were recaptured within the study sites, but eels were occasionally caught in freshwater tributaries of the Isefjord. At the open coast at South Funen NIELSEN (1989) suggests that strong currents in the area may spread the eels to areas where the fishermen were not informed of the marking experiment.

With a quite different marking method, radioactive europium, ANDERSSON et al. (1991) recaptured $1.3 \%$ and $3.5 \%$ of two stockings of elvers, during 5 years of sampling. Their sampling programme was limited and survival rate was thought to be much higher. From stockings in closed freshwater systems TULONEN and PURSIAINEN (1992) report high recapture rates from 27.4 to $56.1 \%$. In a similar stocking experiment WICKSTRÖM et al. (1994) report recapture rate of $11.3 \%$. 
NIELSEN (1989) noted a time lag between time at marking and release and some minor growth might have taken place before release. Size selectivity of the fishing gear at the study sites may also be of importance. However, mean annual increment between 2.5 and $6.5 \mathrm{~cm}$ is within the expected growth rate (WICKSTRÖM et al., 1994 and ANDERSSON et al., 1991). BISGAARD and PEDERSEN (1991) give absolute growth data from a Danish stream. They released individually tagged cultured eels with a mean length of $20.0 \mathrm{~cm}$, corresponding to the size of small eels in this study. After one year an average length increment of $3.6 \mathrm{~cm}$ (range $0.3-6.6 \mathrm{~cm}$ ) was recorded.

The increasing proportion of females observed during the study at Hjarbæk Fjord (Figure 3) may be a result of male silver eels emigrating from the marked cohort, leaving proportionally more females behind. On the other hand, the batch of large eels were all determined to be males at release. It is generally accepted that the sex of eels is not genetically determined, but sex differentiation of individuals is influenced by environmental factors (COLOMBO and ROSSI, 1978 ; COLOMBO and GRANDI, 1996). From histological studies of gonads, COLOMBO and GRANDI (1996) find that testis (syski organ) contain oocytes from which ovaries can be differentiated until a body length up to $34 \mathrm{~cm}$, which makes the eel very sex labile. HOLMGREN and MOSEGAARD (1996) suggest that early growth status may influence the future sex of sexual undifferentiated eels. Their results indicate that fast growing individuals turn into males. This may contribute to the explanation that males were dominating in the first year and later turned out to be females in the following years.

\section{REFERENCES}

ANDERSSON J., SANDSTÖM O., HANSEN H.J.M., 1991. Elver (Anguilla anguilla L.) stockings in a Swedish thermal effluent - recaptures, growth and body condition. $J$. Appl. lchthyol., 7, 78-89.

BERG S., JØRGENSEN J., 1994. Stocking experiments with O+ eels (Anguilla anguilla L.) in Danish streams : post stocking movements, densities and mortality. In COWX I.G. (ed.), Rehabilitation of freshwater fisheries, Fishing News Books, Oxford, 314325.

BISGAARD J., PEDERSEN M.I., 1991. Mortality and growth of wild and introduced cultured eels (Anguilla anguilla (L.)) in a Danish stream, with special reference to a new tagging technique. Dana, vol. 9, 57-69.

COLOMBO G., ROSSI R., 1978. Environmental influences on growth and sex ratio in different eels populations (Anguilla anguilla L.) of Adriatic coasts. In McLUSKY D.S. and BERRY A.J. (eds), Physiology and behavior of marine organism, Proc.12th Euro. Symp. Mar. Biol., Pergamon Press, Oxford, 313-320.

COLOMBO G., GRANDI G, 1996. Histotological study of the development and sex differentiation of the gonad in the European eel. J. Fish Biol., 48, 493-512.

DEKKER W., 1989. Death rate, recapture frequency and changes in size of tagged eels. $J$. Fish Biol., 34, 769-777.

EGUSA S., 1979. Notes on the culture of the European eel (Anguilla anguilla L.) in Japanese eel-farming ponds. Rapp. P.-v. Reun. Cons. int. Explor. Mer, 174, 51-58.

HAGSTRÖM O., WICKSTRÖM H., 1990. Immigration of young eels to the Skagerak Kattegat area 1900 to 1989. Int. Revue ges. Hydrobiol., 75 (6), 707-716.

HART P.J.B., PITCHER T.J., 1969. Field trials of fish marking using a jet inoculator. $J$. Fish Biol., 1, 383-385.

HOLMGREN K., MOSEGAARD H., 1996. Implications of individual growth status on the future sex of the European eel. J. Fish Biol., 49, 910-925. 
MORIARTY C., 1990. European catches of elver 1928 - 1988. Int. Revue ges. Hydrobiol., 75 (6), 701.706.

NIELSEN J., 1988. Marking and tagging methods applied to eel, Anguilla anguilla (L.). EIFAC Occas. Pap., (21), 1-24.

NIELSEN L., 1989. Udsætning af mærkede ál (Release of marked eels). Statusrapport, Danish Institute for Fisheries and Marine Research, 26 p. (In Danish)

NIELSEN L., 1990. Udsætning af mærkede ál (Release of marked eels). Statusrapport, Danish Institute for Fisheries and Marine Research, 15 p. (In Danish)

RASMUSSEN G., GEERTZ-HANSEN P., 1998. Stocking of fish in Denmark. In COWX I.G. (ed.), Stocking and introduction of fish, Fishing News Books, Oxford, 14-21.

SINHA V.R.P., JONES J.W., 1966. On the sex and distribution of the freshwater eel (Anguilla anguilla L.). J. Zool. Lond., 150, 99-117.

TULONEN J., PURSIAINEN M., 1992. Eel stockings in the waters of the Evo State Fisheries and Aquaculture Research Station. Suomen Kalatalous, 60, 246-261. (In Finnish with English summary)

WICKSTRÖM H., WESTIN L., CLEVESTAM P., 1996. The biological and economic yield from a long-term eel-stocking experiment. Ecology of Freshwater Fish, 5, 140-147. 